\title{
Classification of Coefficients of Variation in Experiments with Commercial layers
}

\section{Author(s)}

Faria Filho DE*

Dias AN

Veloso ALC

Bueno CFD

Couto FAP

Matos Júnior JB

Barreto KZO

Rodrigues PA

Carneiro WA

Universidade Federal de Minas Gerais

Instituto de Ciências Agrárias

M ontes Claros, M inas Gerais, Brasil.

\section{Mail Address}

DE Faria Filho

Av. Universitária, n. 1000

Bairro universitário. Caixa Postal 135

39.404-006. Montes Claros, M G, Brasil.

E-mail: fariafilho@ufmg.br

\section{Keywords}

Experimental accuracy, experimental statistics, Gallus domesticus, poultry.

\section{ABSTRACT}

This study aimed at determining a specific classification of coefficients of variation in experiments with commercial layers. Coefficients of variation were collected from papers published in Brazilian journals between 2000 and 2009 for performance, internal egg quality, and eggshell quality parameters. The coefficients of variation of each parameter w ere classified as low, intermediate, high, and very high according to the ratio between the median and the pseudo-sigma. It was concluded that the parameters used in experiments with commercial layers have a specific classification of coefficients of variation, and that this must be considered to evaluate experimental accuracy.

\section{INTRODUCTION}

In analysis of variance models, the coefficient of variation (CV) is calculated as the residual standard deviation expressed as a percentage of the general mean of the experiment. The residual standard deviation is the square root of the error mean square, which contains all the variation due to the experimental error. Therefore, $\mathrm{CV}$ is an important measure of experimental precision. The lower the CV, the higher the precision of the experiment for a determined parameter. Low-precision experiments increase the chances of type II errors, when the difference among treatments is considered non-significant, when it is in fact significant (Sampaio, 1998). Therefore, CVs need to be classified in order to allow researchers to evaluate the results of their studies and those published in literature.

Each response parameter presents a specific CV classification. CV classification ranges were already established for pigs (Judice et al., 1999), beef cattle (Judice et al., 2002), equine nutrition (Lana et al., 2006), and broilers (M ohallem et al., 2008). How ever, no CV classification was yet established for parameters commonly evaluated in studies with commercial layers.

This study aimed at determining a classification of CVs of performance and internal and external egg quality parameters in experiments with commercial layers.

\section{MATERIAL AND METHODS}

The journals Acta Scientiarium, Arquivo Brasileiro de Medicina Veterinária and Zootecnia, Ciência and Agrotecnologia, Ciência Animal Brasileira, Ciência Rural, Pesquisa Agropecuária Brasileira, Revista Brasileira de Ciência Avícola, Revista Brasileira de Zootecnia, and Scientia Agrícola were reviewed. These journals were accessed via internet, and papers involving commercial layers in lay were search in the title and abstract in all numbers published between 2000 and 2009. 
Faria Filho DE, Dias AN, Veloso ALC, Bueno CFD, Couto FAP, Matos Júnior JB, Barreto KZO, Rodrigues PA, Carneiro WA

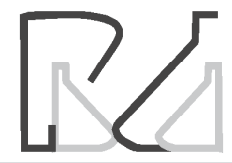

Among the selected articles, the $\mathrm{CV}$ of the parameters feed intake (g/bird/day), egg production (\%/bird/day), egg weight (g), egg mass ( $g /$ bird/day), feed conversion ratio per dozen eggs (g/dozen), feed conversion ratio per egg mass $(\mathrm{g} / \mathrm{g})$, Haugh units, eggshell thickness (mm), and egg specific gravity $(\mathrm{g} / \mathrm{mL})$ was collected.

For the CV of each parameter, the number of observations, minimum and maximum values, mean, standard deviation, median, and pseudo-sigma were determined (Tukey, 1977). Data normality was verified by the test of Cramer-Von-Mises (Littell et al., 2002). CV classification ranges followed the methodology proposed by Costa et al. (2002) as a function of median ( $\mathrm{Md}$ ) and pseudo-sigma (PS), as follows: low (CV $\leq \mathrm{Md}$ - PS), intermediate ( $M d-P S<C V \leq M d+P S)$, high (Md $+\mathrm{PS}<\mathrm{CV} \leq \mathrm{Md}+2 \mathrm{PS}$ ) and very high (CV $>\mathrm{Md}+2 \mathrm{PS})$. Statistical analysis were performed using $\mathrm{SAS}^{\circledR}$ software package (Littell et al., 2002).

\section{RESULTS AND DISCUSSION}

Descriptive statistical analysis and CV normality test for the studied parameters are shown in Table 1. None of the analyzed parameters presented normal distribution according to the test of Cramer-Von-M ises. Therefore, the methodology of CV classification proposed by Costa
Classification of Coefficients of Variation in Experiments w ith Commercial layers

et al. (2002), which does not assume data normality, was adopted.

The CV classification ranges for parameters used in experiments with commercial layers are presented in Table 2. When there is not a specific CV classification for the studied parameter, researchers usually resort to their experience or the classifications proposed in literature, such as that of Gomes (2000), which was established with crop data, but that is used to compare CVs in animal science. Gomes (2000) established as low CVs those lower than $10 \%$, intermediate CVs as those between 10 and $20 \%$, high CVs as those between 20 and $30 \%$, and very high CVs as those higher than $30 \%$. This CV classification is very different from that proposed in the present study. In the classification of Gomes (2000), a CV of $10 \%$ is considered as low, whereas in the present study it is considered very high for feed intake, egg production, eggshell thickness, and specific gravity, and very high for the remaining parameters. This stresses the importance of establishing specific CV classifications, as currently proposed for crops (Clemente \& M uniz, 2002; Costa et al., 2002; Carvalho et al., 2003; Lima et al., 2004; Oliveira et al., 2009) and animal production (Judice et al., 1999; Judice et al., 2002; Lana et al., 2006; M ohallem et al., 2008), allowing researchers to verify the accuracy of their own results and of those published in literature.

\begin{tabular}{|c|c|c|c|c|c|c|c|c|}
\hline Parameter & $\mathbf{N}$ & Min & Max & Mean & SD & Median & PS & Nomality \\
\hline $\mathrm{Fl}$ & 90 & 0.43 & 11.76 & 4.42 & 2.35 & 3.99 & 2.30 & $0.17 *$ \\
\hline EP & 100 & 1.31 & 22.35 & 6.33 & 3.99 & 5.99 & 3.73 & $0.34 * *$ \\
\hline EW & 99 & 0.5 & 11.96 & 3.17 & 1.87 & 2.93 & 1.06 & $1.44 * *$ \\
\hline EM & 69 & 2.06 & 21.32 & 6.49 & 3.48 & 6.03 & 2.22 & $0.39 * *$ \\
\hline FCR dozen & 51 & 1.23 & 19.25 & 6.01 & 3.20 & 5.63 & 2.62 & $0.16 *$ \\
\hline FCR mass & 74 & 1.9 & 21.18 & 6.29 & 3.41 & 6.01 & 3.01 & $0.22 * *$ \\
\hline $\mathrm{HU}$ & 45 & 0.61 & 41.05 & 6.7 & 8.54 & 4.45 & 3.02 & $1.16 * *$ \\
\hline EST & 40 & 0.11 & 12.67 & 3.02 & 2.12 & 2.60 & 1.04 & $0.54 * *$ \\
\hline SG & 57 & 0.08 & 3.38 & 0.62 & 0.89 & 0.31 & 0.24 & $1.88^{* *}$ \\
\hline
\end{tabular}

\begin{tabular}{|c|c|c|c|c|}
\hline Parameter & Low & Intermediate & High & Very high \\
\hline $\mathrm{Fl}$ & $C V \leq 1.68$ & $1.68<C V \leq 6.29$ & $6.29<C V \leq 8.59$ & $C V>8.59$ \\
\hline EP & $C V \leq 2.25$ & $2.25<\mathrm{CV} \leq 9.72$ & $9.72<\mathrm{CV} \leq 13.45$ & $C V>13.45$ \\
\hline EW & $C V \leq 1.87$ & $1.87<C V \leq 3.98$ & $3.98<\mathrm{CV} \leq 5.04$ & $\mathrm{CV}>5.04$ \\
\hline EM & $C V \leq 3.81$ & $3.81<C V \leq 8.25$ & $8.25<C V \leq 10.47$ & $C V>10.47$ \\
\hline FCR dozen & $C V \leq 3.01$ & $3.01<\mathrm{CV} \leq 8.25$ & $8.25<C V \leq 10.86$ & $C V>10.86$ \\
\hline FCR mass & $C V \leq 2.99$ & $2.99<\mathrm{CV} \leq 9.02$ & $9.02<C V \leq 12.03$ & $C V>12.03$ \\
\hline $\mathrm{HU}$ & $C V \leq 1.43$ & $1.43<\mathrm{CV} \leq 7.47$ & $7.47<\mathrm{CV} \leq 10.49$ & $C V>10.49$ \\
\hline EST & $C V \leq 1.56$ & $1.56<C V \leq 3.64$ & $3.64<C V \leq 4.68$ & $C V>4.68$ \\
\hline SG & $C V \leq 0.07$ & $0.07<C V \leq 0.55$ & $0.55<\mathrm{CV} \leq 0.78$ & $C V>0.78$ \\
\hline
\end{tabular}


Faria Filho DE, Dias AN, Veloso

ALC, Bueno CFD, Couto FAP, Matos Júnior JB, Barreto KZO, Rodrigues PA, Carneiro WA
Classification of Coefficients of Variation in Experiments with Commercial layers

\section{CONCLUSION}

It was concluded that performance and internal and external egg quality parameters used in studies with commercial layers have a specific classification of coefficients of variation, and that this must be considered for the evaluation of experimental data accuracy.

\section{REFERENCES}

Carvalho CGP, Arias CAA, Toledo JFF, Almeida LA, Kiihl RAS, Oliveira M F, Hiromoto DM, Takeda C. Proposta de classificação dos coeficientes de variação em relação à produtividade e altura da planta de soja. Pesquisa Agropecuária Brasileira 2003; 38(2):187-193.

Clemente AL, Muniz JA. Avaliação do coeficiente de variação em experimentos com gramíneas forrageiras. Ciência e Agrotecnologia 2002; 24(3):738-742.

Costa NHAD, Seraphin JC, Zimmermann FJP. Novo método de classificação de coeficientes de variação para a cultura do arroz de terras altas. Pesquisa Agropecuária Brasileira 2002; 37:243-249.

Gomes FP. Curso de estatística experimental. 13 ed. São Paulo: Nobel; 2000

Lana AMQ, Soares Neto J, Almeida FQ, Rezende ASC, Prates RC. Classificação de coeficientes de variação na experimentação com nutrição de equinos. Arquivo Brasileiro de Medicina Veterinária e Zootecnia 2006; 58:854-859.

Judice MG, Muniz JA, Carvalheiro R. Avaliação do coeficiente de variação na experimentação com suínos. Ciência e Agrotecnologia 1999; 23:170-173.

Judice MG, Muniz JA, Aquino LH, Bearzoti E. Avaliação da precisão experimental em ensaios com bovinos de corte. Ciência e Agrotecnologia 2002; 26:1035-1040.

Lima LL, Nunes GHS, Bezerra Neto F. Coeficientes de variação de algumas características do meloeiro: uma proposta de classificação. Horticultura Brasileira 2004; 22:14-17.

Littell RC, Stroup WW, Freund RJ. SAS for linear models. 4th ed. Cary: SAS Institute; 2002.

Mohallem DF, Tavares M, Silva PL, Guimarães EC, Freitas RF. Avaliação do coeficiente de variação com medida de precisão em experimentos com frangos de corte. Arquivo Brasileiro de Medicina Veterinária e Zootecnia 2008; 60:449-453.

Oliveira RL, M uniz JÁ, Andrade JB, Reis RL. Precisão em ensaios com a cultura do feijão. Ciência e Agrotecnologia 2009; 33:113-119.

Sampaio IBM. Estatística aplicada à experimentação animal. Belo Horizonte: FEPM VZ; 1998.

Tukey JW. Exploratory data analysis. Reading: Addison-Wesley; 1977. 